症例

成人大網囊腫の 1 例

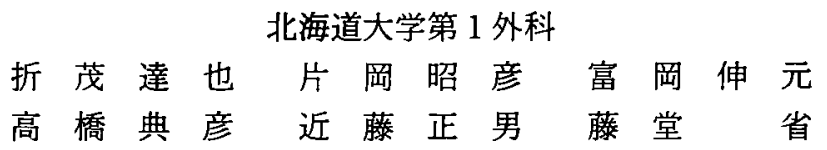

症例は 35 歳の女性. 1 年 9 カ月前からの腹部違和感を主訴に当科を受診した。上腹部 正中に大きさ $10 \times 10 \mathrm{~cm}$ の可動性良好な腫瘤を触知し, またCT 検査, 超音波検査で腹腔 ほほ正中に最大径 $13 \mathrm{~cm}$ の襄胞性腫瘤を認めた。腸間膜壤腫もしくは大網㖶腫の診断で 摘出術を施行した. 手術所見では, 腫湯は大網より発生していた. 摘出標本は大きさ $20 \times$ $16 \times 5 \mathrm{~cm}$, 重量 $590 \mathrm{~g} て ゙$, 病理組織学的には悪性所見は認めず, cystic lymphangioma で あった.

大網謽腫は小児期に発症することが多い比較的稀な疾患である．臨床症状は軽微なこ とが多いが，中には急性腹症として発症する症例もあり，治療は手術による襄腫摘出術 である.

索引用語：大網䨢腫, omental cyst

\section{緒言}

大網襄腫は約 $68 \%$ が10歳未満の若年者に発症する比 較的稀な疾患である”．臨床症状は軽微なことが多い が，中には急性腹症として発症する症例もあり"1), 治療 は手術による㖶腫摘出術が第一選択である，今回われ われは成人に発生した大網筫腫の 1 例を経験したので 報告する。

症例 : 35歳, 女性.

主訴：腹部違和感.

現病歴：2003年 9 月, 腹部違和感があり子宮癌検診 を受けたが，異常は指摘されなかった．2005年 4 月 4 日の子宮癌検診では卵巣䧶腫を疑われ，5月19日当院 婦人科受診となった。しかし襄腫は他臟器由来の可能 性が高いと診断され，当科紹介受診，入院となった。

既往歴：1993年 2 月右卵巣破裂で手術. 1994年 1 月, 1995年 7 月帝王切開。

家族歴：特記すべきことなし。

現症：身長 $154.7 \mathrm{~cm}$ ，体重 $46.5 \mathrm{~kg}$ ．自覚症状は腹部 の圧迫感のみであった. 上腹部正中に大きさ $10 \times 10 \mathrm{~cm}$

2005年10月20日受付 2005年10月28日採用 〈所属施設住所〉

于060-8648 札幌市北区北十四条西 5 丁目
の可動性良好な腫瘤を触知し，圧痛は認めなかった。

検查所見：一般血液, 生化学検査で異常所見を認め なかった．腫瘍マーカー (CEA 4.7ng/ml, CA19-9< $1.0 \mathrm{U} / \mathrm{ml}, \mathrm{CA} 2516.72 \mathrm{U} / \mathrm{ml}$, NSE $9.3 \mathrm{ng} / \mathrm{ml}$, TPA 18U/L) も正常範囲内であった。

腹部単純 $\mathbf{X}$ 線検査：一部に小腸ガスを認め, 腫瘤の 圧迫によるものと考えられた（図 1).

腹部超音波検査：腹腔ほぼ正中に大きさ $10 \times 5 \mathrm{~cm}$ の衰胞性腫瘤を認めた。内部に充実性成分は認めなか った(図 2 )。

腹部 CT 検查：腹腔ほほ正中に最大径 $13 \mathrm{~cm}$ の境界 明暸な腫瘤を認めた。内部に充実性成分はなく，明ら かな周囲への浸潤所見もなかった（図 3 ).

以上より腸間膜襄腫もしくは大網㐮腫の診断で, 2005 年 6 月 28 日手術を施行した。

手術所見：腫瘍は胃大彎と横行結腸の間に存在し， 大網より発生していた．壤胞壁を損傷することなく囊 腫を摘出した（図 4 ).

摘出標本：大きさ $20 \times 16 \times 5 \mathrm{~cm}$, 重量 $590 \mathrm{~g}$ で, 内容 液は淡黄色漿液性であった（図 5 )。

病理組織学的所見：一層の扁平な内皮細胞が䨢胞壁 を覆っており，襄胞壁を構成する細胞に悪性所見を認 めなかった。内皮マーカーである factor VIIIが裏胞壁を 覆う細胞で一部陽性であることより cystic lymphan. 


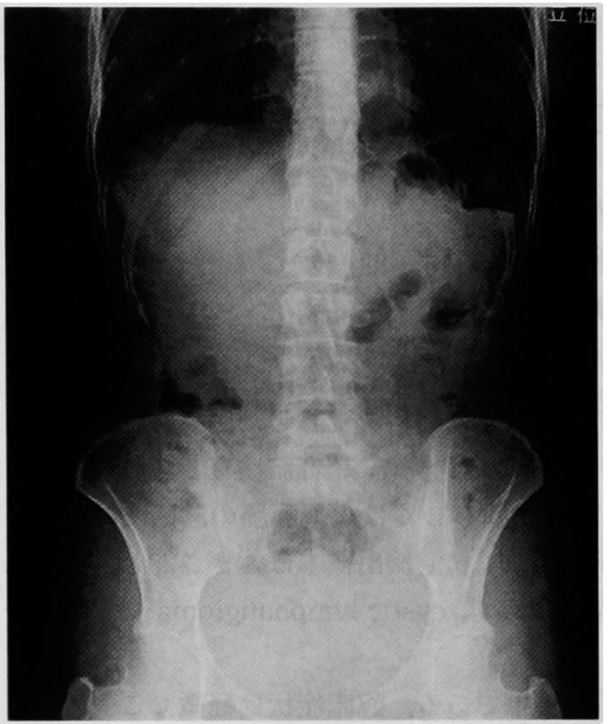

図 1 腹部単純 $\mathrm{X}$ 線検查：一部に小腸ガスを認 め，腫瘤の压迫によるものと考えられた。

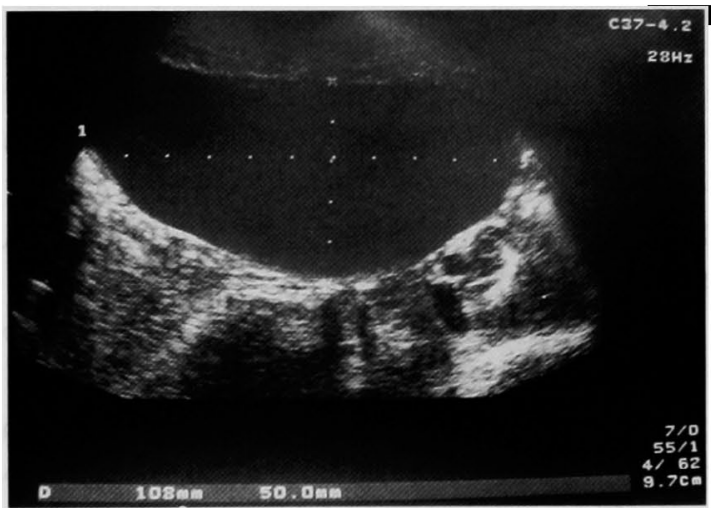

図 2 腹部超音波検査：腹腔ほほ正中に大きさ $10 \times 5 \mathrm{~cm}$ の㖶胞性腫瘤を認めた。

gioma と診断した（図 6 ).

術後経過：経過良好で術後13日目に退院した。

\section{考察}

大網裏腫は新生児期から成人まで幅広く認められる が，特に10歳未満の若年者に多く，約 $68 \%$ を占める”。 腸間膜と大網は発生学的に同一であり，腸間膜哓腫と

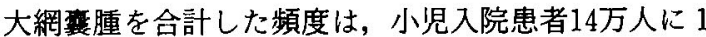
人とされている ${ }^{233)}$. 部位別の割合は腸間膜が79\%，大 網が14\%，両者に合併が $7 \%$ とされる2).

大網震腫の組織学的分類は, 1 ) リンパ霊腫 (cystic

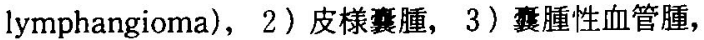

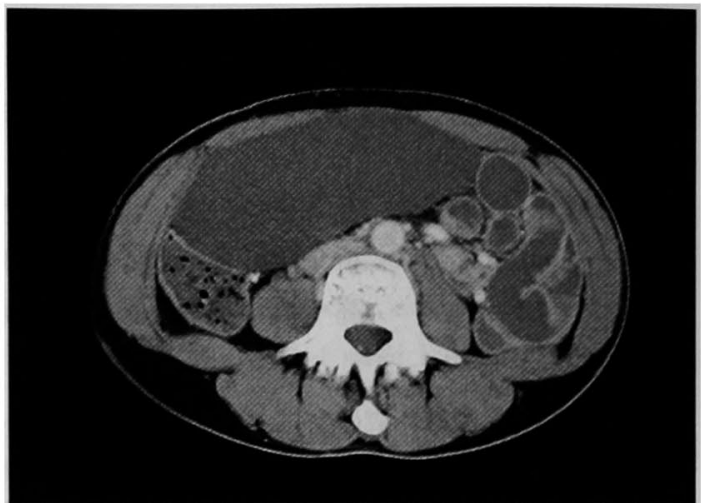

図 3 腹部 CT 検査：腹腔ほぽ正中に最大径 $13 \mathrm{~cm}$ の境界 明瞭な腫溜を認めた。

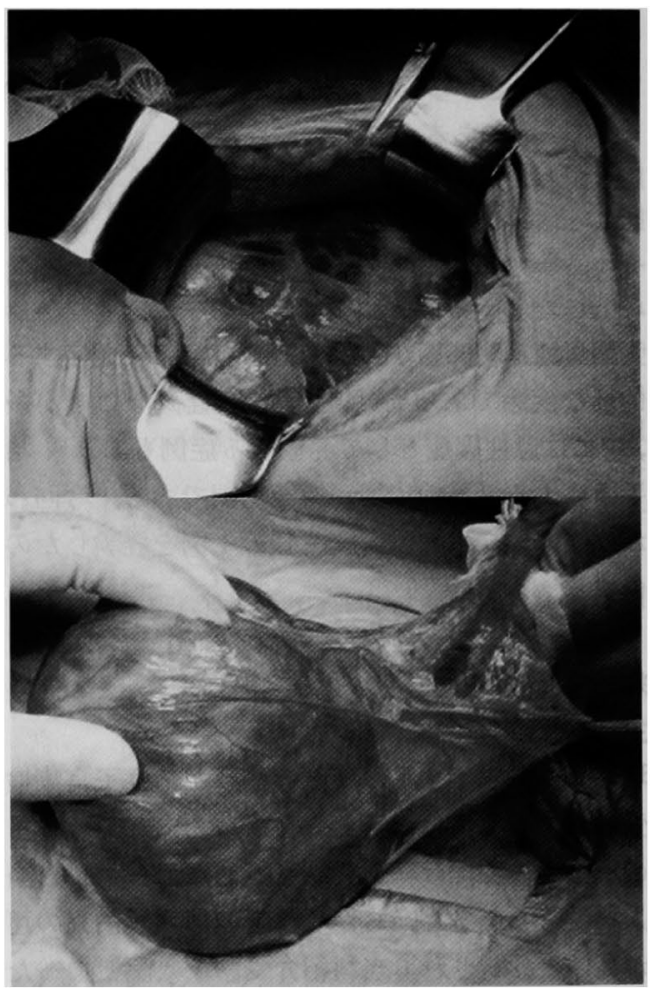

図 4 手術所見：腫瘍は胃大彎側と横行結腸の間に 存在し，大網より発生していた。

4）繁液性または粘液性薯腫，5）大網膜の炎症性機 転による襄腫性変化の 5 つに分けられることが多く， この中でも cystic lymphangioma が全体の約 $68 \%$ を 占め ${ }^{1 / 3) 41}$, 自験例も病理組織学的検查 で cystic lymphangioma であった。本症の発生機序については 


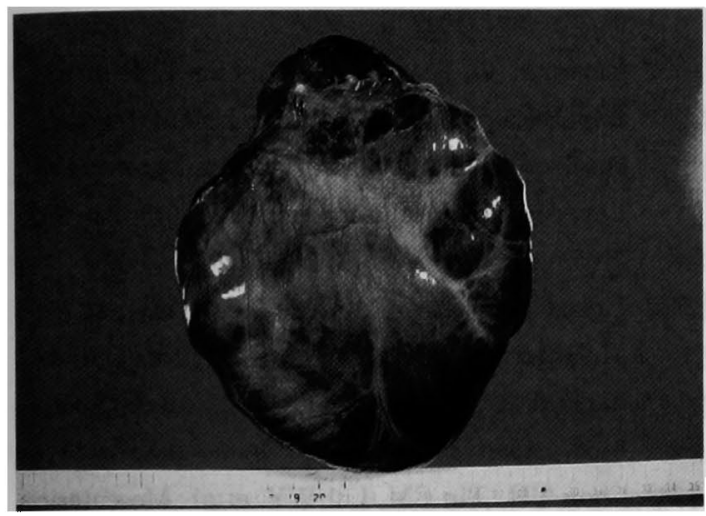

図 5 摘出標本：大きさ $20 \times 16 \times 5 \mathrm{~cm}$, 重量 $590 \mathrm{~g}$ て, 内 容液は淡黄色焚液性であった。

諸説あり,リンパ管組織の発生障害説, 組織の自律増 殖を伴うリンパ管新生物説，機械的閉塞によるリンパ うっ滞説, リンパ説の萁胞性変性説，外傷説などであ $3^{115)}$.

臨床症状は腹部膨隆, 腹痛, 腹部腫瘤触知が三大症 状であり，他に圧迫による胃腸症状，呼吸障害，排尿 障害などを示す場合もある ${ }^{115)}$ 。しかし一般に臨床症状 は軽いことが多く，無症状で手術時や剖検時に偶然発 見されることもある”。一方，急性腹症として発症する 症例も $23.8 \%$ あり，原因としては茎捻転が最も多く，

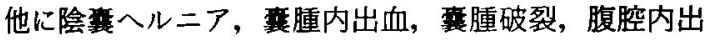
血，腸閉塞などがある ${ }^{45)}$.

本症の術前診断は困難で，術前診断率は13\%といわ れていたが゙，近年では超音波検査やCT 検査, MRI 検 査の普及によって診断可能な症例が増加してきてい ろ.

鑑別疾患としては, 腸間膜襄腫, 卵巣喜腫, 膵襄腫, 虫垂炎, 腹膜炎のほか, 腎腫瘤, 脾腫, 遊走腎, 結核 性腹膜炎，胃腸腫瑒などがあり，特に小児では Wilms 腫場，神経芽細胞腫，奇形腫などとの鑑別が必要であ $3^{1 !}$.

治療は敦腫摘出術が行われる6) 99. 前述のように,大 網憝腫は茎捻転などにより急性腹症を呈することもあ るので，無症状でも外科的に旁腫摘出を行うのが適切 と考えられている4．自験例では 3 回の開腹歴がある ため開腹手術を行ったが，腹腔鏡手術を行う症例も報 告されておりり占，症例によっては検討すべき方法で あると思われる。本症は完全摘出できれば予後は良好 である10)111.

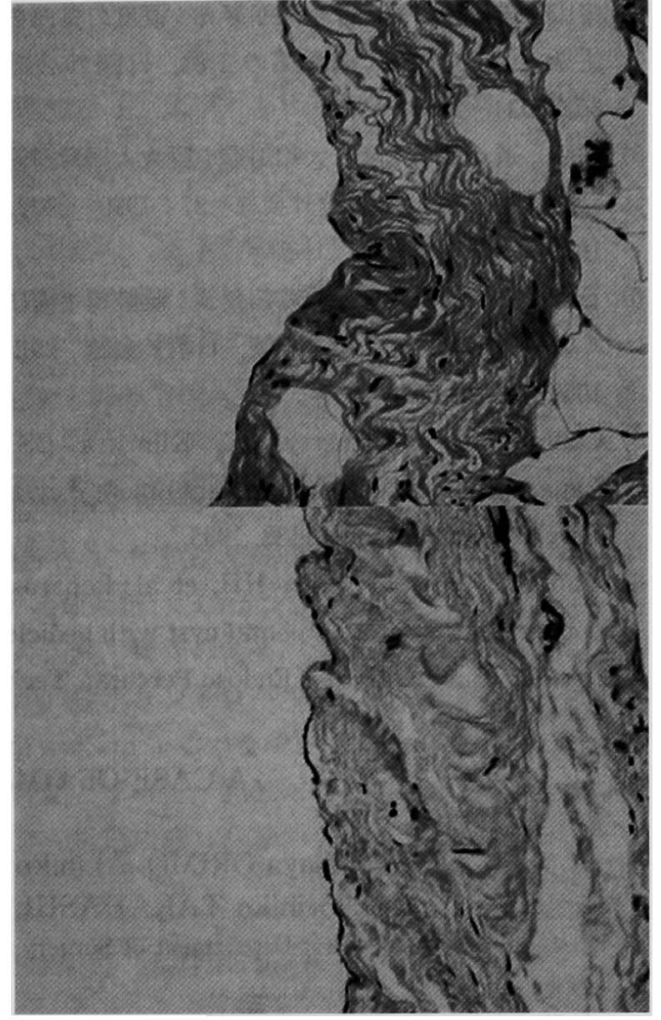

図 6 病理組織学的所見：上）HE 染色, $\times 20$. 扁平 な内皮細胞が董胞壁を覆っており, 車胞壁を構成 する細胞に悪性所見を認めなかった，下)内皮マー カーである factor VIIIが亭胞壁を覆う細胞で一部 陽性であることより cystic lymphangioma と診 断した.

\section{結 語}

成人に発生した大網亳腫の 1 例を経験したので報告 した.

稿を終えるにあたり，御指導を賜りました当院病理部の 久保田佳奈子先生，伊藤智雄先生に㳭謝いたしま寸。

\section{文献}

1）小川正道，岩村春樹，山村 京他：急性腹症を呈 した大網毫腫の 1 例一本邦における大網襄腫124 例の検討一。小児臨 $36: 1505-1510 ， 1983$

2) Egozi EI, Ricketts RR:Mesenteric and omental cysts in children. Am Surg $63: 287-$ 290, 1997

3）馬場美子，松尾吉庸，川口竜介他：血性腹水症状 を呈した，巨大大網咅腫の 1 例. 日小児外会誌 $36: 100-104,2000$ 
4）中山善文，楠田慎一，永㴊幸寿 他：高度の貧血を 主徵とした乳児大網莗腫の 1 例. 日臨外会誌 $60: 1934-1937,1999$

5）川手 進, 六本木隆, 大和田進：巨大大網英腫性 リンパ管腫の 1 例. 日消外会誌 $27 ： 1999-2002$, 1994

6）石和直樹, 野口芳一，福澤邦康他：腹腔鏡手術に て摘出しえた大網咅腫の1例. 日消外会誌 29 ： $1069-1073,1996$

7) Conlon KC, Dougherty EC, Klimstra DS : Laparoscopic resection of a giant omental cyst. Surg Endosc $9:$ 1130-1132, 1995

8) Yao CC, Wu TL, Wong $\mathrm{HH}$, et al : Laparoscopic resection of an omental cyst with pedicle torsion. Surg Laparosc Endosc Percutan Tech
$9: 372-374,1999$

9) Giovanni C, Riccardo V, Grazia EM, et al: Laparoscopic treatment of an omental cyst : a case report and review of the literature. Surg Laparosc Endosc Percutan Tech $15: 33-35$, 2005

10) Hebra A, Brown MF, McGeehin KM, et al : Mesenteric, omental, and retroperitoneal cysts in children : a clinical study of 22 cases. South Med J $86: 173-176,1993$

11) Chou YH, Tiu CM, Lui WY, et al: Mesenteric and omental cysts: an ultrasonographic and clinical study of 15 patients. Gastrointest Radiol 16:311-314, 1991

\title{
A CASE OF OMENTAL CYST IN ADULT
}

\author{
Tatsuya ORIMO, Akihiko KATAOKA, Nobumoto TOMIOKA, \\ Norihiko TAKAHASHI, Masao KONDO and Satoru TODO \\ First Department of Surgery, Hokkaido University School of Medicine
}

A 35-year-old woman was admitted to the hospital because of abdominal distension. An abdominal mass was palpable, and both ultrasonography and computed tomography revealed an intraabdominal cystic tumor which was $10 \times 5 \mathrm{~cm}$ in size. Under a diagnosis of omental cyst or mesenteric cyst, a laparotomy was performed. The cystic tumor was located in the greater omentum, and the excision of the tumor was performed. The histological diagnosis was cystic lymphangioma. Omental cyst is relatively rare, and it can be seen more often in children than in adults. The treatment of choice is complete excision, which provides a good prognosis. 